\title{
Amperometric Formaldehyde Sensor Based on a Pd Nanocrystal Modified C/Co 2 P Electrode
}

\author{
Huan Wang, ${ }^{1}$ Yaodan Chi, ${ }^{1,2}$ Xiaohong Gao, ${ }^{1}$ Sa Lv, ${ }^{1}$ Xuefeng Chu, ${ }^{1}$ Chao Wang, \\ Lu Zhou, ${ }^{1}$ and Xiaotian Yang ${ }^{1}$ \\ ${ }^{1}$ Jilin Provincial Key Laboratory of Architectural Electricity \& Comprehensive Energy Saving, Department of Materials Science, \\ Jilin Jianzhu University, Changchun 130118, China \\ ${ }^{2}$ College of Instrumentation \& Electrical Engineering, Jilin University, Changchun 130012, China \\ Correspondence should be addressed to Xiaotian Yang; hanyxt@163.com
}

Received 20 June 2017; Revised 27 September 2017; Accepted 10 October 2017; Published 12 November 2017

Academic Editor: C. R. Raj

Copyright (C) 2017 Huan Wang et al. This is an open access article distributed under the Creative Commons Attribution License, which permits unrestricted use, distribution, and reproduction in any medium, provided the original work is properly cited.

\begin{abstract}
Ultrafine Pd nanocrystals were grown on the cobalt phosphide $\left(\mathrm{Co}_{2} \mathrm{P}\right)$ decorated Vulcan XC-72 carbon $\left(\mathrm{C} / \mathrm{Co}_{2} \mathrm{P}\right)$, which is realized by first implementing the corresponding metal precursor and then the further chemical reduction process. The as-synthesized $\mathrm{C} / \mathrm{Co}_{2} \mathrm{P} / \mathrm{Pd}$ composite was further constructed to form a gas permeable electrode. This electrode can be applied for formaldehyde $(\mathrm{HCHO})$ detection. The results demonstrate that the $\mathrm{Co}_{2} \mathrm{P}$ nanocrystal can significantly improve the sensing performance of the $\mathrm{C} / \mathrm{Co}_{2} \mathrm{P} / \mathrm{Pd}$ electrode for catalytic oxidation of $\mathrm{HCHO}$, which is considered to be attributed to the effective electron transfer from $\mathrm{Co}_{2} \mathrm{P}$ to $\mathrm{Pd}$ in the $\mathrm{C} / \mathrm{Co}_{2} \mathrm{P} / \mathrm{Pd}$ composites. Furthermore, the assembled $\mathrm{C} / \mathrm{Co}_{2} \mathrm{P} / \mathrm{Pd}$ sensor exhibits high sensitivity of $617 \mathrm{nA} / \mathrm{ppm}$ and good selectivity toward various interfering gases such as $\mathrm{NO}_{2}, \mathrm{NO}, \mathrm{SO}_{2}, \mathrm{CO}_{2}$, and $\mathrm{CO}$. It also shows the excellent linear response that the correlation coefficient is 0.994 in the concentration range of $1-10 \mathrm{ppm}$. Therefore, the proposed cost-effective $\mathrm{C} / \mathrm{Co}_{2} \mathrm{P} / \mathrm{Pd}$ nanocomposite, which owns advantages such as high activity and good stability, has the potential to be applied as an effective electrocatalyst for amperometric HCHO detection.
\end{abstract}

\section{Introduction}

Formaldehyde, which is a colorless and toxic volatile organic compound (VOC), is an essential material that is applied in many aspects including the chemical factories and the residence decorating field. It is also well known that the formaldehyde can significantly increase the probability to get cancer for people [1]. Therefore, the detection of formaldehyde gas is significantly important. Until now, numerous technologies have been employed, such as spectrophotometry [2], gas chromatography (GC) [3], high-performance liquid chromatography [4], ion chromatography [5], polarography [6], and integrated sensor [7]. Among the above-mentioned techniques, the gas sensors have been widely reported by many research groups due to the advantages of high sensitivity, fast response, high stability, small size, and cost-effective features. In addition, these small packaged sensors can be mass fabricated easily in order to satisfy the large demand in many industrial fields. Generally, there are two types of formaldehyde gas sensor: (1) semiconductors formaldehyde gas sensor based on metal oxide such as $\mathrm{SnO}_{2}[8,9], \mathrm{ZnO}$ [10], $\mathrm{In}_{2} \mathrm{O}_{3}[11,12]$, and $\mathrm{NiO}[13]$ and (2) amperometric formaldehyde gas sensor made from noble metal nanomaterial, such as platinum or gold $[14,15]$. In contrast with semiconductor gas sensor, the amperometric formaldehyde gas sensors have numerous advantages such as lower power consumption, excellent linear response, high sensitivity, and reasonable selectivity at room temperature.

Due to their high catalytic activity and excellent chemical stability, Pt-based catalysts are generally used in amperometric gas sensor. However, the scarcity and high cost of platinum greatly hinder its application. Much effort has been devoted to developing the platinum-free electrocatalysts, among which palladium-containing catalysts have been proven to be an effective candidate $[16,17]$. The $\mathrm{C} / \mathrm{Pd}$ catalyst is a good choice, due to its low cost and competitive intrinsic electrocatalytic 

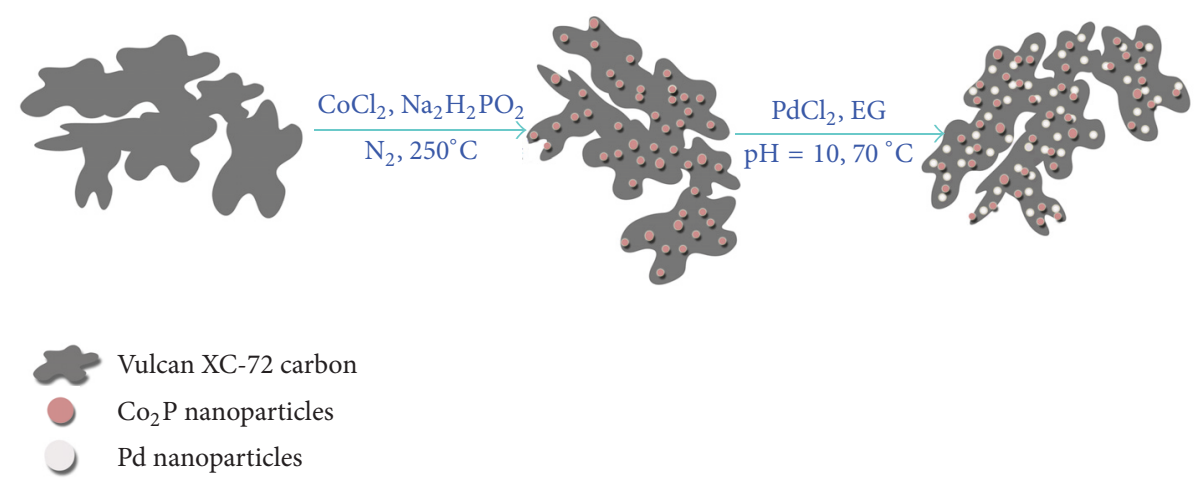

Figure 1: Synthesis procedure of Pd nanoparticle-modified $\mathrm{C} / \mathrm{Co}_{2} \mathrm{P}$ composites.

activity [18]. Furthermore, it is reported that the addition of another element, such as $\mathrm{Fe}, \mathrm{Co}, \mathrm{Ni}, \mathrm{N}$, or $\mathrm{P}$, can enhance the catalytic activity of the C/Pd catalyst [19-22]. Unfortunately, the catalytic performance decreases rapidly by the dissolution or instability of the addition elements. It is well known that the transition metal phosphide nanoparticles such as $\mathrm{Ni}_{2} \mathrm{P}$, $\mathrm{CoP}$, and $\mathrm{FeP}$ can significantly improve the catalytic activity and stability of catalyst [23-25]. But only a few works were reported about metal phosphide nanoparticles decorated $\mathrm{Pd} / \mathrm{C}$ hybrids.

In this work, an amperometric formaldehyde gas sensor was fabricated by using the $\mathrm{C} / \mathrm{Co}_{2} \mathrm{P} / \mathrm{Pd}$ catalyst as active electrode in $\mathrm{H}_{2} \mathrm{SO}_{4}$ electrolyte. The obtained $\mathrm{C} / \mathrm{Co}_{2} \mathrm{P} / \mathrm{Pd}$ sensor exhibits better sensing performance for $\mathrm{HCHO}$ detection than that of the $\mathrm{C} / \mathrm{Co}_{2} \mathrm{P}$ and $\mathrm{C} / \mathrm{Pd}$ sensor.

\section{Experiment Section}

2.1. Materials. Vulcan XC-72 carbon powder (99.9\%) was purchased from Cabot Co. (USA). Sodium hypophosphite (99\%), sodium hydroxide (99.9\%), cobalt nitrate hexahydrate (99.99\%), ethylene glycol (99.99\%), ethanol (99.99\%), and hydrochloric acid (37 wt.\%) were purchased from Beijing Beihua Chemicals Co., Ltd. Nafion solution (5\%) was purchased from DuPont Co. Palladium chloride (99.9\%) was purchased from Tianjin Guangfu Chemicals Co., Ltd. Highly purified nitrogen $(\geq 99.99 \%)$ and oxygen $(\geq 99.99 \%)$ were supplied by Changchun Juyang Co., Ltd. Formaldehyde, nitric oxide, nitrogen dioxide, sulfur dioxide, ammonia, and carbon monoxide were supplied by Dalian Special Gases Co., Ltd.

2.2. Preparation of $\mathrm{Co}_{2} \mathrm{P}$ Modified $\mathrm{Pd} / \mathrm{C}$ Composites. Pd modified $\mathrm{C} / \mathrm{Co}_{2} \mathrm{P}$ composite was synthesized by solid phase reaction and ethylene glycol reduction according to a reported method [18, 23, 26, 27] and the corresponding schematic illustration is shown in Figure 1. Typically, $0.5 \mathrm{~g}$ Vulcan $\mathrm{XC}-72$ was added to $20 \mathrm{~mL}$ aqueous solution containing $0.664 \mathrm{~g} \mathrm{CoCl}_{2}$. Then the mixed solution was stirred overnight followed by drying at $120^{\circ} \mathrm{C}$ for $5 \mathrm{~h}$. The resulting Vulcan $\mathrm{XC}-72$ containing $\mathrm{CoCl}_{2}$ and $1.46 \mathrm{~g} \mathrm{NaH} \mathrm{PO}_{2} \cdot \mathrm{H}_{2} \mathrm{O}$ was mechanically mixed in a quartz boat at room temperature. The precursor was directly heated to $250^{\circ} \mathrm{C}$ and was kept for $1 \mathrm{~h}$ under $\mathrm{N}_{2}$ flowing condition. Then it was cooled to room temperature. The resulting $\mathrm{C} / \mathrm{Co}_{2} \mathrm{P}$ composite was passivated in a $1.0 \mathrm{~mol} \% \mathrm{O}_{2} / \mathrm{N}_{2}$ mixture for $3 \mathrm{~h}$. The obtained sample was washed with deionized water and was dried at $80^{\circ} \mathrm{C}$ for $24 \mathrm{~h}$.

The $41.6 \mathrm{mg} \mathrm{PdCl}_{2}$ and $100 \mathrm{mg} \mathrm{C} / \mathrm{Co}_{2} \mathrm{P}$ composites were dispersed into ethylene glycol (EG, $60 \mathrm{ml}$ ) followed by sonicating for $1 \mathrm{~h}$ under ambient condition. Then the solution was further stirred for $5 \mathrm{~h}$. Its $\mathrm{pH}$ value was adjusted to 10 by $1 \mathrm{M} \mathrm{NaOH}$ solution. Then the mixture was placed in water bath and was heated at $70^{\circ} \mathrm{C}$ for $3 \mathrm{~h}$ with vigorous stirring. After reaction, its $\mathrm{pH}$ value was adjusted to 3 by adding hydrochloric acid and then incubated overnight. The resulting product was collected by vacuum filtration and was washed with hot deionized water and ethanol, and the resulting $\mathrm{C} / \mathrm{Co}_{2} \mathrm{P} / \mathrm{Pd}$ composites were dried at $80^{\circ} \mathrm{C}$ for $12 \mathrm{~h}$. For comparison, the $\mathrm{C} / \mathrm{Pd}$ composite was prepared under the same condition.

2.3. Preparation of Modified Electrodes. The glass carbon electrodes (GCE, $d=3 \mathrm{~mm}$ ) surfaces were carefully polished to a mirror using alumina slurries with different diameter (1.0, 0.3 , and $0.05 \mathrm{~mm}$ ) and then thoroughly cleaned ultrasonically with ethanol and deionized water. Subsequently, $5 \mu \mathrm{L}$ of homogeneous $\mathrm{C} / \mathrm{Co}_{2} \mathrm{P}, \mathrm{C} / \mathrm{Pd}$, and $\mathrm{C} / \mathrm{Co}_{2} \mathrm{P} / \mathrm{Pd}$ dispersion $\left(5 \mathrm{mg} \mathrm{mL}^{-1}\right)$ was dropped onto the surface of GCEs, respectively. After being dried at room temperature for $24 \mathrm{~h}$, three modified GCEs were obtained and denoted as $\mathrm{C} / \mathrm{Co}_{2} \mathrm{P} / \mathrm{GCE}$, $\mathrm{C} / \mathrm{Pd} / \mathrm{GCE}$, and $\mathrm{C} / \mathrm{Co}_{2} \mathrm{P} / \mathrm{Pd} / \mathrm{GCE}$. Each working of $\mathrm{C} / \mathrm{Pd}$ and $\mathrm{C} / \mathrm{Co}_{2} \mathrm{P} / \mathrm{Pd}$ electrodes contained ca. $15 \mu \mathrm{g} / \mathrm{cm}^{2}$ of $\mathrm{Pd}$.

2.4. Fabrication and Measurement of Gas Sensor. Amperometric $\mathrm{HCHO}$ sensor was fabricated by the method depicted in Figure 2. Circular working electrode (diameter: $1 \mathrm{~cm}$, area: $0.785 \mathrm{~cm}^{2}$ ) was prepared as follows: $2.0 \mathrm{mg}$ of catalyst was dispersed in ethanol $(0.25 \mathrm{~mL})$ containing $1 \mu \mathrm{L}$ of $0.5 \mathrm{wt} \%$ Nafion ethanol solution to form homogenous suspension by sonication. The mixture was sprayed onto the porous PTFE membrane (PM 28Y, Porex) and was dried at room temperature. The $\mathrm{Pd}$ density of the $\mathrm{C} / \mathrm{Co}_{2} \mathrm{P} / \mathrm{Pd}$ electrode was $0.667 \mathrm{mg} / \mathrm{cm}^{2}$. The platinum wire counter electrode and $\mathrm{Ag} / \mathrm{AgCl}$ (in $3 \mathrm{M} \mathrm{KCl}$ ) reference electrode were then inserted into the sensor housing. The electrolyte is $0.5 \mathrm{M} \mathrm{H}_{2} \mathrm{SO}_{4}$. The distances among the three electrodes are all equal to $6 \mathrm{~cm}$. 


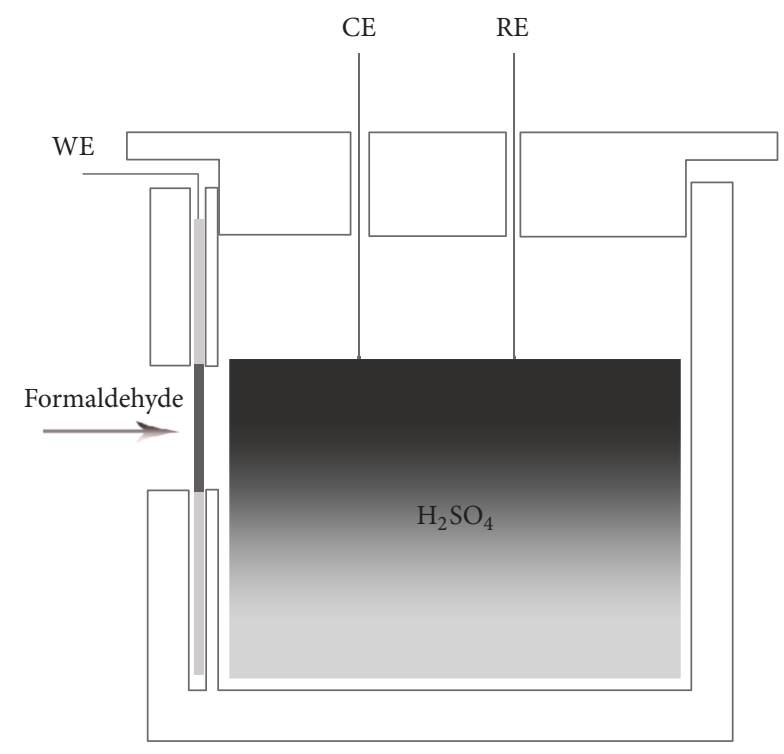

FIGURE 2: Schematic illustration of formaldehyde gas sensor.

2.5. Characterizations. Transmission electron microscope (TEM), high-resolution TEM (HRTEM) (TEM, JOEL TEM2010), scanning electron microscope (SEM, Phenom ProX), and energy-dispersive X-ray (EDX, Phenom ProX) were employed to inspect the morphologies and composition of samples. X-ray photoelectron spectroscopy (XPS) analysis was performed on an ESCALAB-MKII X-ray photoelectron spectrometer (VG Co.) with $\mathrm{Al} \mathrm{Ka} \mathrm{X-ray} \mathrm{radiation} \mathrm{as} \mathrm{the} \mathrm{X}$ ray source for excitation. Cyclic voltammetric (CV) and the gas sensing properties were performed by a CHI660C electrochemical workstation (CHI). A conventional three-electrode cell comprises a modified GCE or prepared membrane as working electrode, a platinum wire as the auxiliary electrode, and $\mathrm{Ag} / \mathrm{AgCl}$ (in $3 \mathrm{M} \mathrm{KCl}$ ) as reference electrode. All the gas sensors were polarized in $0.5 \mathrm{M} \mathrm{H}_{2} \mathrm{SO}_{4}$ solution for $24 \mathrm{~h}$ at $0.75 \mathrm{~V}$ prior to amperometric measurements. Amperometric responses were measured to various gases of $\mathrm{HCHO}, \mathrm{NO}_{2}$, $\mathrm{NO}, \mathrm{SO}_{2}, \mathrm{CO}_{2}$, and $\mathrm{CO}$ at the applied potential of $0.75 \mathrm{~V}$ (versus $\mathrm{Ag} / \mathrm{AgCl}$ ). The standard gases of $\mathrm{HCHO}, \mathrm{NO}_{2}, \mathrm{NO}$, $\mathrm{SO}_{2}, \mathrm{CO}_{2}$, and $\mathrm{CO}$ were purchased from Dalian Special Gases Co., Ltd. The detection gas was mixed by using a mass flow controller which was linked to one $\mathrm{N}_{2}$ chamber and a $\mathrm{HCHO}$ standard chamber. Different gas concentration can be obtained by modulating the mass flow controller digitally.

\section{Results and Discussion}

3.1. Morphology and Component Characterization. Figure 3 shows the XRD patterns of the Vulcan XC-72 carbon (a), C/ $\mathrm{Co}_{2} \mathrm{P}$ composites (b), C/Pd composite (c), and the $\mathrm{C} / \mathrm{Co}_{2} \mathrm{P} / \mathrm{Pd}$ composite $(\mathrm{d})$, wherein a (002) peak is observed at $24.5^{\circ}$ from the XC-72 carbon. After solid phase reaction, the $\mathrm{Co}_{2} \mathrm{P}$ nanoparticles are loaded on the XC-72 carbon. The major peaks at $40.7^{\circ}(121), 40.9^{\circ}(201), 43.2^{\circ}$ (211), and $48.7^{\circ}$ (031) of the $\mathrm{C} / \mathrm{Co}_{2} \mathrm{P}$ composites are well matched with standard Joint Committee on Powder Diffraction Standards (JCPDS) card number 32-0306 for orthorhombic $\mathrm{Co}_{2} \mathrm{P}[28,29]$. The XRD

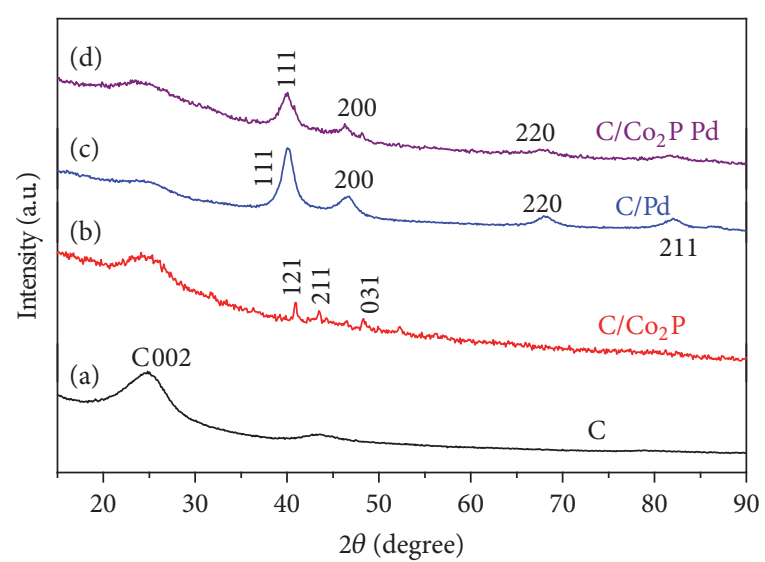

Figure 3: X-ray diffraction patterns for the Vulcan XC-72 carbon (a), $\mathrm{C} / \mathrm{Co}_{2} \mathrm{P}$ composite (b), C/Pd composite (c), and the $\mathrm{C} / \mathrm{Co}_{2} \mathrm{P} / \mathrm{Pd}$ composite (d).

pattern of C/Pd clearly shows the peaks of metallic state $\mathrm{Pd}$ (JCPDS file: 65-2867) (Figure 3(c)). The XRD pattern of the $\mathrm{C} / \mathrm{Co}_{2} \mathrm{P} / \mathrm{Pd}$ composite (Figure $3(\mathrm{~d})$ ) indicates the successful deposition of Pd nanoparticles by comparison with that of $\mathrm{C} / \mathrm{Pd}$ (Figure 3(c)). However, the peaks of $\mathrm{Co}_{2} \mathrm{P}$ are not observed in the $\mathrm{C} / \mathrm{Co}_{2} \mathrm{P} / \mathrm{Pd}$ composite, which may be due to the $\mathrm{Pd}$ nanoparticles coated on the $\mathrm{C} / \mathrm{Co}_{2} \mathrm{P}$ supporters. The presence of $\mathrm{Co}_{2} \mathrm{P}$ was confirmed by EDX and element distribution maps, and the results are similar to the previous report [23].

Morphology and element distribution of the $\mathrm{C} / \mathrm{Co}_{2} \mathrm{P} / \mathrm{Pd}$ composites were characterized by TEM, HRTEM, SEM, EDX, and elemental mapping techniques. Figures 4(a) and 4(b) show the typical TEM and HRTEM images of the $\mathrm{C} / \mathrm{Co}_{2} \mathrm{P} / \mathrm{Pd}$ composites. As shown in Figure 4(b), a nanocrystal particle was indicated by a red circle having a finger lattice of $0.21 \mathrm{~nm}$, which is corresponding to the $\mathrm{Co}_{2} \mathrm{P}$ (211) lattice [28]. In addition, the distances among the adjacent lattice fringes in the crystalline regions, which are marked by green circles, are $0.23 \mathrm{~nm}$. This value is agrees well with the $\mathrm{d}$ spacing $\mathrm{Pd}$ (111) plane that the literature value is $0.229 \mathrm{~nm}$ (JCPDS number 65-6174). In order to further illustrate the surface chemical composition of the $\mathrm{C} / \mathrm{Co}_{2} \mathrm{P} / \mathrm{Pd}$ composites, XPS measurements were performed from Figures 4(c)-4(f).

As shown in Figure 4(c), the survey XPS spectrum confirms the presence of $\mathrm{C}, \mathrm{O}, \mathrm{Pd}, \mathrm{Co}$, and $\mathrm{P}$ in the $\mathrm{Pd} / \mathrm{Co}_{2} \mathrm{P} / \mathrm{C}$ composites. Figure $4(\mathrm{~d})$ shows the XPS spectrum of $\mathrm{Pd}_{3 \mathrm{~d}}$ in $\mathrm{C} / \mathrm{Co}_{2} \mathrm{P} / \mathrm{Pd}$ composites. Two typical peaks at around $335.2 \mathrm{eV}$ and $340.4 \mathrm{eV}$ were corresponding to $\mathrm{Pd}_{3 \mathrm{~d} 5 / 2}$ and $\mathrm{Pd}_{3 \mathrm{~d} 3 / 2}$, respectively, which are located at 335.8 and $341.2 \mathrm{eV}$ for the C/Pd composite (Figure S1) [30]. Such significant shift indicates a partial electron transfer from $\mathrm{Co}_{2} \mathrm{P}$ to $\mathrm{Pd}$ [23]. This would increase the electron density of $\mathrm{Pd}$. The unobvious peaks of $\mathrm{P}_{2 \mathrm{p}}$ and $\mathrm{Co}_{2 \mathrm{p}}$ are ascribed to $\mathrm{Co}_{2} \mathrm{P}$ in the $\mathrm{C} / \mathrm{Co}_{2} \mathrm{P} / \mathrm{Pd}$ composites, indicating the low content of the $\mathrm{Co}$ and $\mathrm{P}$ element on the surface of the $\mathrm{C} / \mathrm{Co}_{2} \mathrm{P} / \mathrm{Pd}$ composites.

Figure 5 shows SEM image (a), element mapping images (b)-(f), and EDX spectrum (g) of the $\mathrm{C} / \mathrm{Co}_{2} \mathrm{P} / \mathrm{Pd}$ composites. SEM image indicates that the obtained $\mathrm{C} / \mathrm{Co}_{2} \mathrm{P} / \mathrm{Pd}$ 


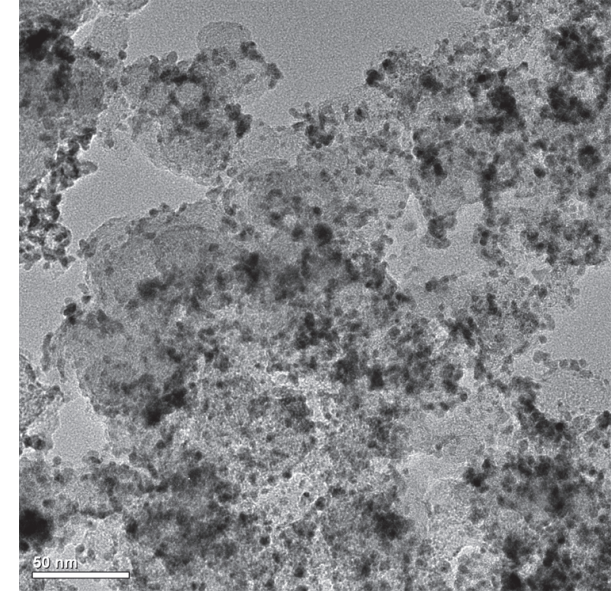

(a)

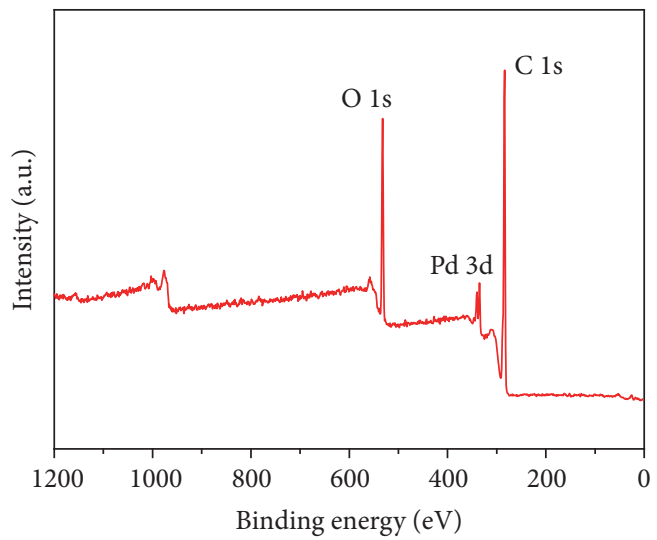

(c)

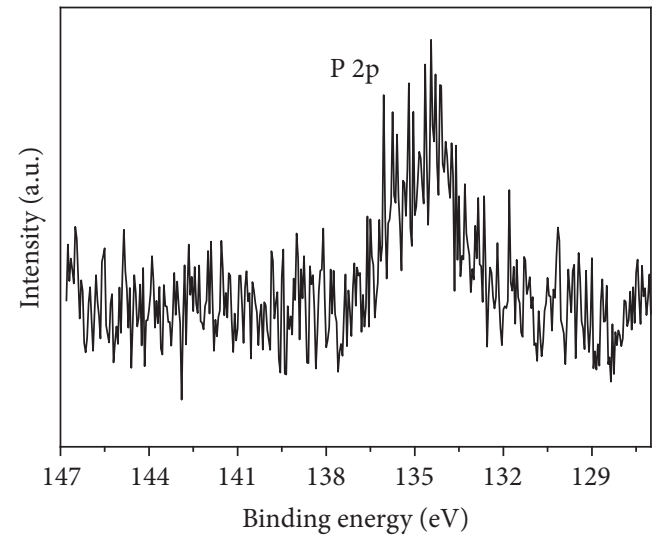

(e)

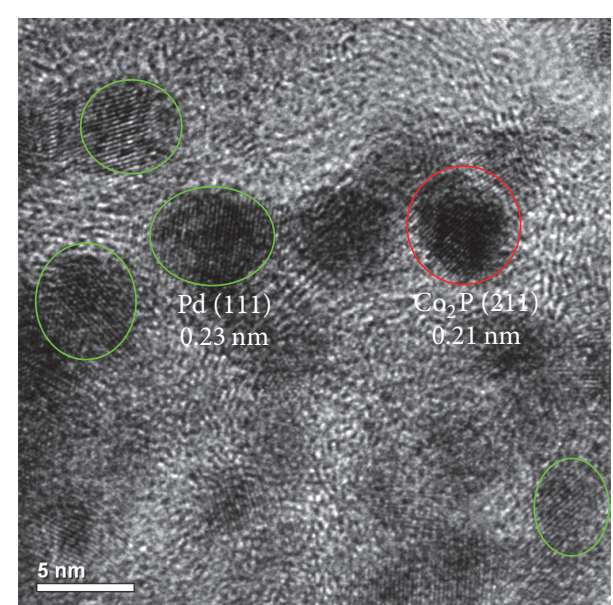

(b)

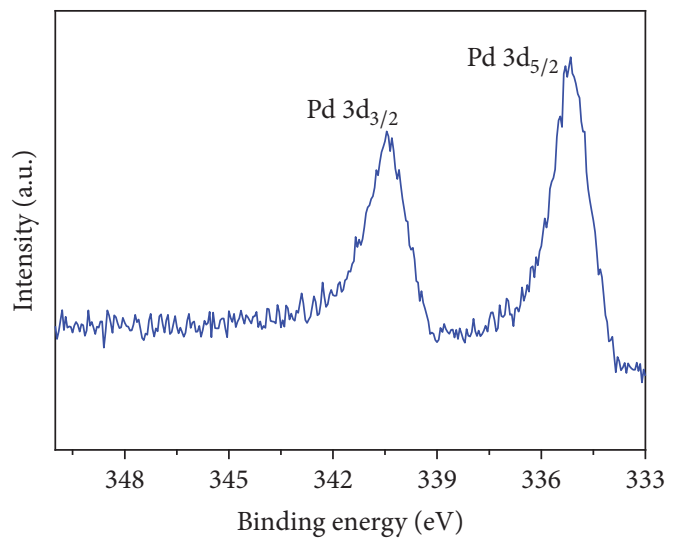

(d)

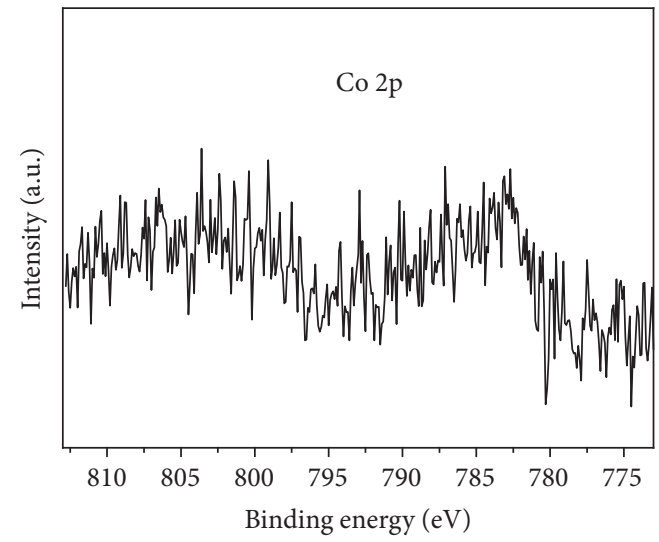

(f)

Figure 4: The TEM (a), HRTEM (b), and the survey, Pd 3d, P 2p, and Co 2p XPS spectra (c)-(f) of the C/Co $\mathrm{Co}_{2} \mathrm{P} / \mathrm{Pd}$ composites.

composites are assembled of nanoparticles. As shown in Figures $5(\mathrm{~b})-5(\mathrm{f})$, the element distribution of the $\mathrm{C} / \mathrm{Co}_{2} \mathrm{P} / \mathrm{Pd}$ composites was investigated by the element mapping, which clearly reveals the existence of $\mathrm{C}, \mathrm{Pd}, \mathrm{O}, \mathrm{Co}$, and $\mathrm{P}$ element in the $\mathrm{C} / \mathrm{Co}_{2} \mathrm{P} / \mathrm{Pd}$ composites. This result is coincident with the XPS spectra of the $\mathrm{C} / \mathrm{Co}_{2} \mathrm{P} / \mathrm{Pd}$ composites. Furthermore, EDX spectrum confirms the presence of $\mathrm{C}, \mathrm{O}, \mathrm{Pd}, \mathrm{Co}$, and $\mathrm{P}$ in the $\mathrm{Pd} / \mathrm{Co}_{2} \mathrm{P} / \mathrm{C}$ composite.
3.2. Electrochemical Properties of the $\mathrm{C} / \mathrm{Co}_{2} \mathrm{P} / \mathrm{Pd}$ Composites Electrodes. Figure 6(a) shows the cyclic voltammetry (CV) curves of the $\mathrm{C} / \mathrm{Co}_{2} \mathrm{P} / \mathrm{GCE}(\mathrm{A}), \mathrm{C} / \mathrm{Pd} / \mathrm{GCE}(\mathrm{B})$, and $\mathrm{C} / \mathrm{Co}_{2} \mathrm{P} / \mathrm{Pd} / \mathrm{GCE}(\mathrm{C})$ in $0.5 \mathrm{M} \mathrm{H}_{2} \mathrm{SO}_{4}$ solution in potential range of $-0.2-1.0 \mathrm{~V}$. As shown in Figure 6(A), no current could be observed on the $\mathrm{C} / \mathrm{Co}_{2} \mathrm{P} / \mathrm{GCE}$. It can be seen that the $\mathrm{CV}$ curves of the C/Pd/GCE exhibited the characteristic $\mathrm{Pd}$ electrochemical reactions in $\mathrm{H}_{2} \mathrm{SO}_{4}$ solution, 


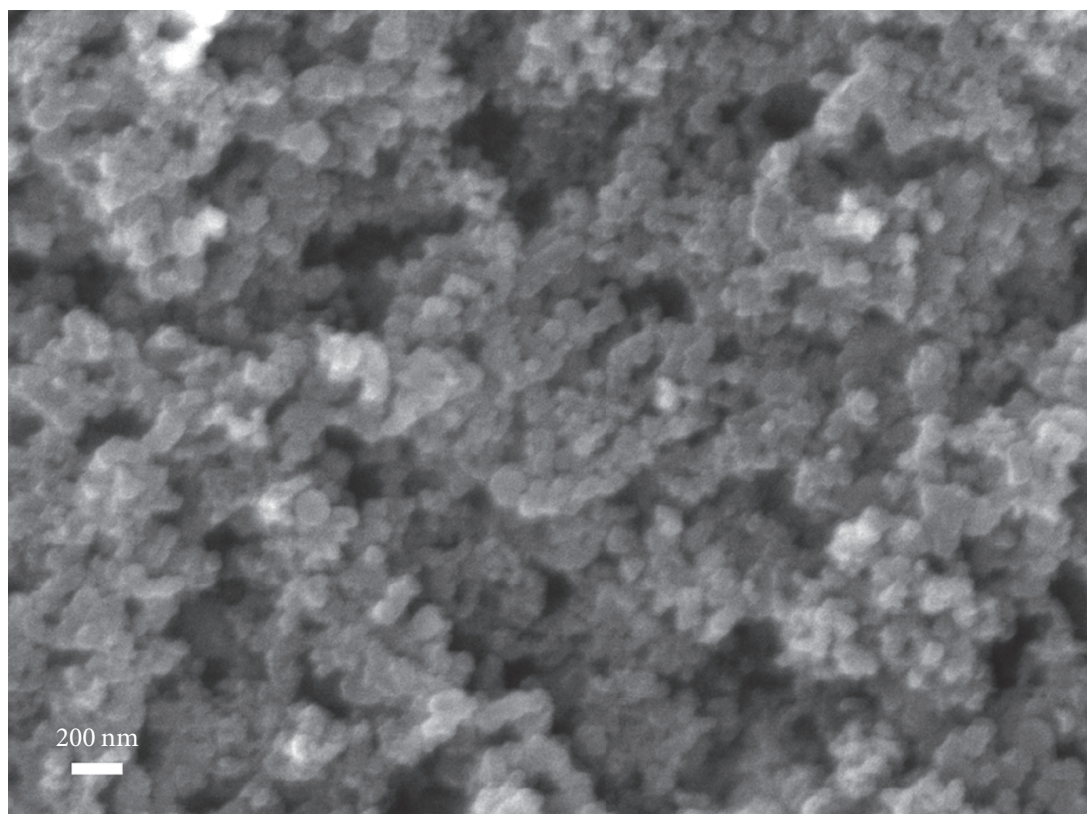

(a)

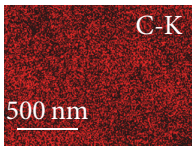

(b)

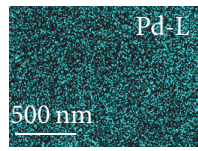

(c)

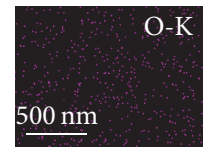

(d)

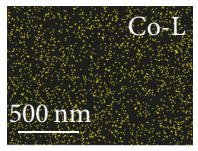

(e)

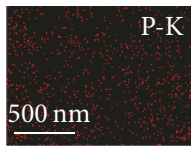

(f)

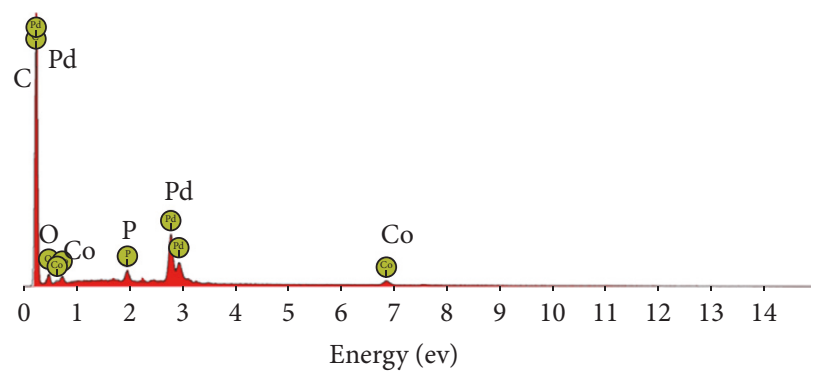

(g)

Figure 5: SEM image (a); element mapping images (b)-(f) for $\mathrm{C}, \mathrm{Pd}, \mathrm{O}, \mathrm{Co}$, and $\mathrm{P}$ in the $\mathrm{C} / \mathrm{Co}_{2} \mathrm{P} / \mathrm{Pd}$ composites and EDX spectrum of the $\mathrm{C} / \mathrm{Co}_{2} \mathrm{P} / \mathrm{Pd}$ composites.

including reversible $\mathrm{H}_{\text {upd }}$ region $(-0.2 \mathrm{~V}-0.1 \mathrm{~V})$ and Pd oxidation/reduction regions. Interestingly, compared with curve $\mathrm{B}$, peak current of curve $\mathrm{C}$ is significantly increased, which is attributed to the strong electronic interaction between $\mathrm{Co}_{2} \mathrm{P}$ and $\mathrm{Pd}$. Figure $6(\mathrm{~b})$ is the $\mathrm{CV}$ curve of $5 \mathrm{mM}$ formaldehyde in $0.5 \mathrm{M} \mathrm{H}_{2} \mathrm{SO}_{4}$ solution at the $\mathrm{C} / \mathrm{Co}_{2} \mathrm{P} / \mathrm{Pd} / \mathrm{GCE}$. In the anodic sweep from 0.2 to $0.9 \mathrm{~V}$, the oxide peak appears at $0.75 \mathrm{~V}$ attributed to the oxidation of $\mathrm{CO}_{\mathrm{ads}}$ intermediate to $\mathrm{CO}_{2}$ on Pd surface during the formaldehyde oxidation. In the successive cathodic sweep, the current peak observed at $0.38 \mathrm{~V}$ was due to the reduction of palladium oxide [31].

In order to compare the catalytic activity of the $\mathrm{C} / \mathrm{Co}_{2} \mathrm{P} /$ GCE, C/Pd/GCE, and $\mathrm{C} / \mathrm{Co}_{2} \mathrm{P} / \mathrm{Pd} / \mathrm{GCE}, \mathrm{CVs}$ of $50 \mathrm{mM}$ formaldehyde in $0.5 \mathrm{M} \mathrm{H}_{2} \mathrm{SO}_{4}$ solution at the three electrodes were measured, which are shown in Figure 7(a). It is found that the $\mathrm{C} / \mathrm{Co}_{2} \mathrm{P} / \mathrm{Pd} / \mathrm{GCE}$ exhibits the relative negative oxidation potential and large current response for a given formaldehyde concentration, indicating that the $\mathrm{C} / \mathrm{Co}_{2} \mathrm{P} / \mathrm{Pd} / \mathrm{GCE}$ has much higher catalytic activity toward the oxidation of formaldehyde than $\mathrm{C} / \mathrm{Co}_{2} \mathrm{P} / \mathrm{GCE}$ and $\mathrm{C} / \mathrm{Pd} / \mathrm{GCE}$. Figure 7 (b) shows $\mathrm{CV}$ responses of the $\mathrm{C} / \mathrm{Co}_{2} \mathrm{P} / \mathrm{Pd} / \mathrm{GCE}$ toward formaldehyde with different concentrations. It is clearly shown that the peak current of formaldehyde increases with the rise of formaldehyde concentration from 0 to $50 \mathrm{mM}$.

Figure 8(a) shows the CVs with different scan rates at the $\mathrm{C} / \mathrm{Co}_{2} \mathrm{P} / \mathrm{Pd} / \mathrm{GCE}$ in the same solution. The result reveals that as the scan rate increased, the forward oxidation peak currents increased and their peak potentials shifted slightly toward positive directions. In the case of backward potential sweep, increasing in the sweeping rate can cause the peak 

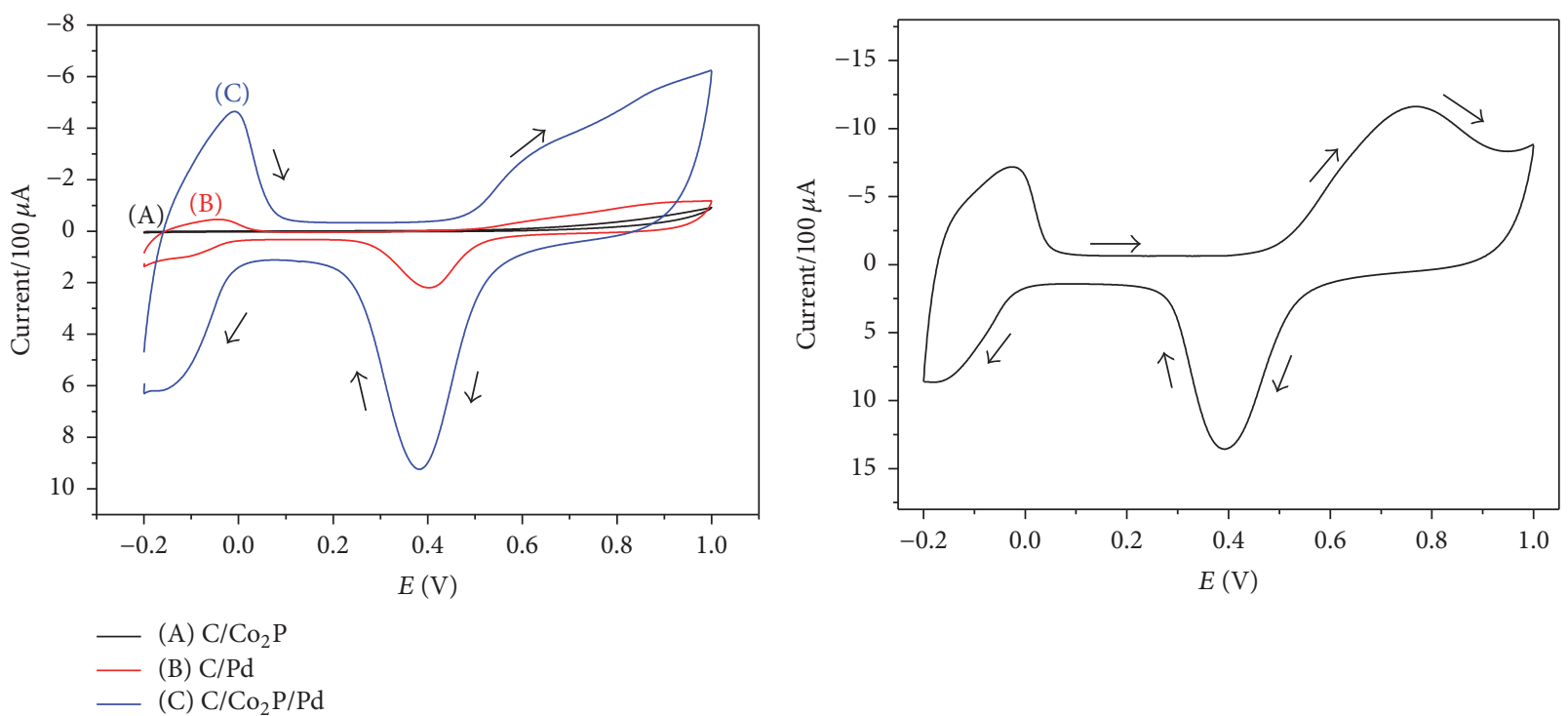

(a)

(b)

Figure 6: (a) CVs of the $\mathrm{C} / \mathrm{Co}_{2} \mathrm{P} / \mathrm{GCE}(\mathrm{A}), \mathrm{C} / \mathrm{Pd} / \mathrm{GCE}(\mathrm{B})$, and $\mathrm{C} / \mathrm{Co}_{2} \mathrm{P} / \mathrm{Pd} / \mathrm{GCE}(\mathrm{C})$ in $0.5 \mathrm{M} \mathrm{H}_{2} \mathrm{SO}_{4}$ solution. Scan rate: $50 \mathrm{mV} / \mathrm{s}$. (b) CV of the $\mathrm{C} / \mathrm{Co}_{2} \mathrm{P} / \mathrm{Pd} / \mathrm{GCE}$ in $0.5 \mathrm{M} \mathrm{H}_{2} \mathrm{SO}_{4}$ solution containing $5 \mathrm{mM}$ formaldehyde from $-0.2 \mathrm{~V}$ to $1.0 \mathrm{~V}$ at $50 \mathrm{mV} / \mathrm{s}$.

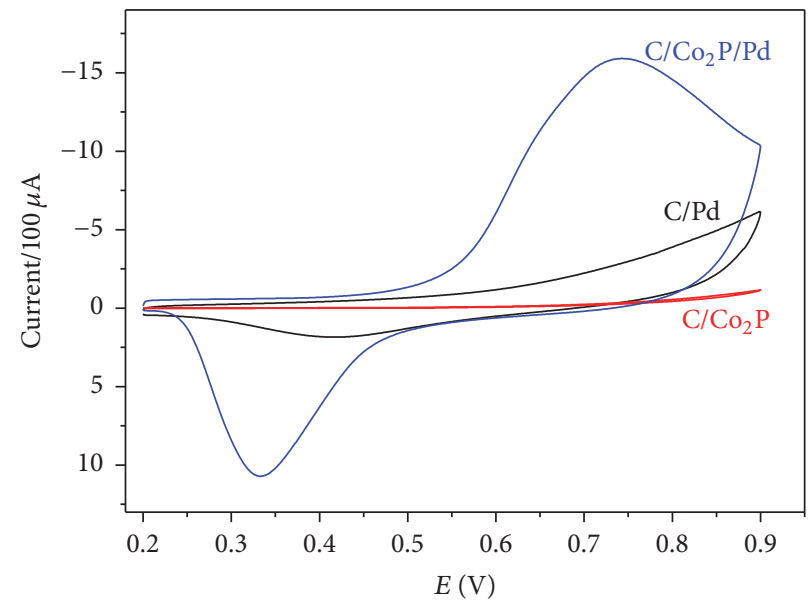

(a)

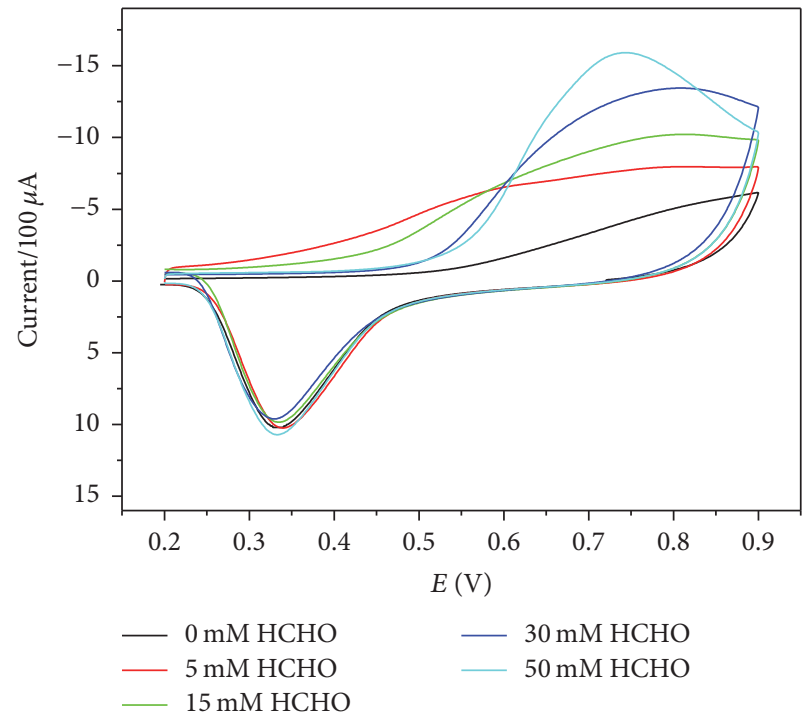

(b)

FIGURE 7: (a) CVs of the different electrodes in $0.5 \mathrm{M} \mathrm{H}_{2} \mathrm{SO}_{4}$ solution containing $50 \mathrm{mM}$ formaldehyde from $0.2 \mathrm{~V}$ to $0.9 \mathrm{~V}$ at $50 \mathrm{mV} / \mathrm{s}$. (b) $\mathrm{CVs}$ of the $\mathrm{C} / \mathrm{Co}_{2} \mathrm{P} / \mathrm{Pd} / \mathrm{GCE}$ in $0.5 \mathrm{M} \mathrm{H}_{2} \mathrm{SO}_{4}$ solution with different concentration of formaldehyde from $0.2 \mathrm{~V}$ to $0.9 \mathrm{~V}$ at scan rate of $50 \mathrm{mV} / \mathrm{s}$.

potential to shift negatively and peak currents increased. The peak current toward formaldehyde oxidation as function of the square root of the scan rate $\left(v^{1 / 2}\right)$ in the range of 10 to $150 \mathrm{mV} \mathrm{s}^{-1}$ is shown in Figure 8(b). A good linear relationship with correlation coefficient of 0.9985 between current response and square root of the scan rate $\left(v^{1 / 2}\right)$ indicates a diffusion-controlled electron transfer process.

3.3. Properties of the Amperometric Gas Sensor. Figure 9(a) presents the amperometric current response of the $\mathrm{C} / \mathrm{Pd}$ (black line), $\mathrm{C} / \mathrm{Co}_{2} \mathrm{P}$ composite (blue line), and $\mathrm{C} / \mathrm{Co}_{2} \mathrm{P} / \mathrm{Pd}$ (red line) sensor. It clearly shows that the $\mathrm{C} / \mathrm{Co}_{2} \mathrm{P} / \mathrm{Pd}$ sensor exhibits a higher current response than that of the $\mathrm{C} / \mathrm{Pd}$ and $\mathrm{C} / \mathrm{Co}_{2} \mathrm{P}$ sensor. The enhanced activity of $\mathrm{C} / \mathrm{Co}_{2} \mathrm{P} / \mathrm{Pd}$ may be attributed to the electron transfer from $\mathrm{Co}_{2} \mathrm{P}$ to $\mathrm{Pd}$, which was demonstrated by XPS (Figure S1 in Supplementary Material available online at https://doi.org/10.1155/2017/2346895) and previous work [23]. Typical dynamic current response for the $\mathrm{C} / \mathrm{Co}_{2} \mathrm{P} / \mathrm{Pd}$ sensor was conducted under different formaldehyde concentrations (Figure 9(b)). It is seen that the peak 


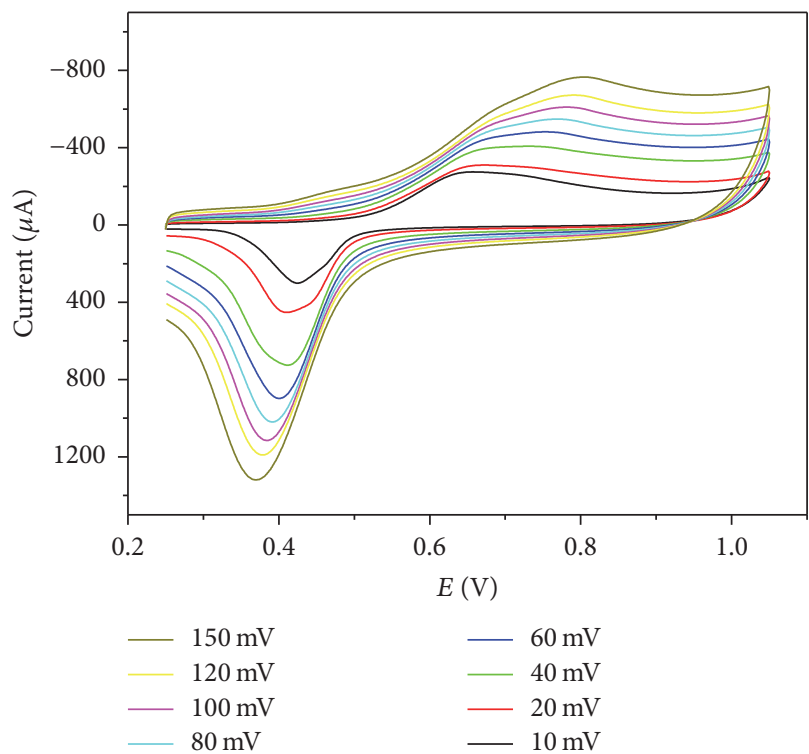

(a)

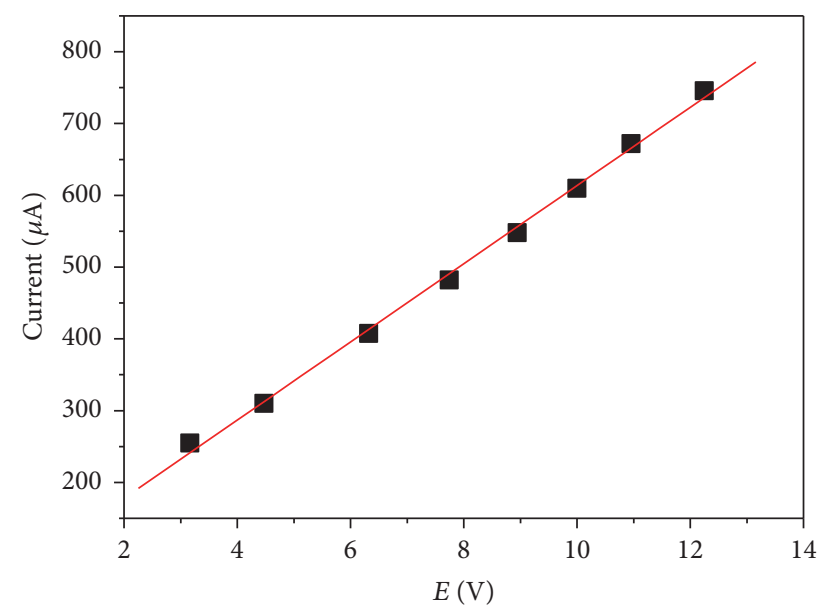

(b)

Figure 8: (a) CVs of the $\mathrm{C} / \mathrm{Co}_{2} \mathrm{P} / \mathrm{Pd} / \mathrm{GCE}$ in $5 \mathrm{mM}$ formaldehyde of $0.5 \mathrm{M} \mathrm{H}_{2} \mathrm{SO}_{4}$ solution with different scan rates $(10,20,40,60,80,100$, 120 , and $150 \mathrm{mV} / \mathrm{s}$ ). (b) The relation of the oxidation current of formaldehyde with square root of scan rate.

current increases linearly with the concentrations of $\mathrm{HCHO}$ from 1 to $10 \mathrm{ppm}$. The calibration curve $(I(\mu \mathrm{A})=3.57+5.70 \mathrm{C}$ $(\mathrm{ppm}) ; R=0.994)$ was obtained from the inset of Figure $8(\mathrm{~b})$, which indicates that the reaction on the $\mathrm{C} / \mathrm{Co}_{2} \mathrm{P} / \mathrm{Pd}$ sensor was limited by the diffusion rate of $\mathrm{HCHO}$ gas [32]. On the basis of Fick's diffusion law, the limiting current $I_{\lim }$ was shown by the following equation [33]:

$$
I_{\lim }=k[\mathrm{HCOH}]_{\mathrm{gas}} \text {, }
$$

where the current is directly proportional to the gaseous concentration. It further indicates that the response is under the diffusion control at steady state.

Figure 9(c) is the enlarged parts of Figure 8(a). It shows that when the $\mathrm{C} / \mathrm{Co}_{2} \mathrm{P} / \mathrm{Pd}$ sensor is exposed to $\mathrm{HCHO}$ gas, its current increases quickly, and it will quickly recover in the absence of $\mathrm{HCHO}$. The response and recovery time are $3.8 \mathrm{~s}$ and $23.1 \mathrm{~s}$, respectively, which are much shorter than those of the $\mathrm{C} / \mathrm{Pd}$ and $\mathrm{C} / \mathrm{Co}_{2} \mathrm{P}$ sensor. The sensitivity of the $\mathrm{C} / \mathrm{Co}_{2} \mathrm{P} / \mathrm{Pd}$ sensor is $617 \mathrm{nA} / \mathrm{ppm}$. The background noise level is about $50 \mathrm{nA}$, which is confirmed by a previous report [34]. The limit of detection (LOD) of the $\mathrm{C} / \mathrm{Co}_{2} \mathrm{P} / \mathrm{Pd}$ sensor is about $0.25 \mathrm{ppm}(\mathrm{S} / \mathrm{N}=3)$. The reproducibility of the $\mathrm{HCHO}$ gas sensor was evaluated in $10 \mathrm{ppm} \mathrm{HCHO} / \mathrm{N}_{2}$ mixture gas at six sensors prepared under the same condition. The RSD $(n=10)$ of the peak current is $3.25 \%$. To evaluate the operational reproducibility of the $\mathrm{C} / \mathrm{Co}_{2} \mathrm{P} / \mathrm{Pd}$ sensor, $i$ - $t$ curves were determined by 10 successive measurements in $10 \mathrm{ppm}$ formaldehyde flow. The obtained RSD is $2.56 \%$, which indicates that the $\mathrm{C} / \mathrm{Co}_{2} \mathrm{P} / \mathrm{Pd}$ sensor can be used for routine analysis of $\mathrm{HCHO}$ in clinical use. The stability of the electrochemical sensor was also studied. After continuous 30 times' measurements, the current response almost does not decrease. The amperometric response with long time test for the $\mathrm{C} / \mathrm{Co}_{2} \mathrm{P} / \mathrm{Pd}$ sensor was studied under continuous $10 \mathrm{ppm}$ formaldehyde flow. No obvious decrease is observed in $400 \mathrm{~s}$, indicating the good stability of the $\mathrm{C} / \mathrm{Co}_{2} \mathrm{P} / \mathrm{Pd}$ sensor (Figure S2).

In order to investigate the selectivity of the $\mathrm{C} / \mathrm{Co}_{2} \mathrm{P} / \mathrm{Pd}$ gas sensor, the amperometric measurements were performed under various testing gases such as $\mathrm{HCHO}, \mathrm{NO}_{2}, \mathrm{NO}, \mathrm{SO}_{2}$, $\mathrm{CO}_{2}$, and $\mathrm{CO}$. Figure 9(d) shows the current response of the $\mathrm{C} / \mathrm{Co}_{2} \mathrm{P} / \mathrm{Pd}$ sensor upon exposure to $10 \mathrm{ppm} \mathrm{HCHO}, 10 \mathrm{ppm}$ $\mathrm{NO}_{2}, 10 \mathrm{ppm} \mathrm{NO}, 10 \mathrm{ppm} \mathrm{SO}, 5000 \mathrm{ppm} \mathrm{CO}$, and $50 \mathrm{ppm}$ $\mathrm{CO}$. The detection selectivity, defined as the relative ratio of the response current of $10 \mathrm{ppm} \mathrm{HCHO}$ to that of $10 \mathrm{ppm} \mathrm{NO}_{2}$, $10 \mathrm{ppm} \mathrm{NO}, 10 \mathrm{ppm} \mathrm{SO}, 5000 \mathrm{ppm} \mathrm{CO}_{2}$, and $50 \mathrm{ppm} \mathrm{CO}$, was $9.3,10.0,33.5,13.2$, and 40.5 , respectively. The as-prepared $\mathrm{C} / \mathrm{Co}_{2} \mathrm{P} / \mathrm{Pd}$ sensor exhibits excellent selectivity for $\mathrm{HCHO}$ detection [33].

\section{Conclusions}

The $\mathrm{C} / \mathrm{Co}_{2} \mathrm{P} / \mathrm{Pd}$ hybrids were successfully synthesized through a two-step method and further applied for fabricating a sensor for detecting $\mathrm{HCHO}$. The results show that the $\mathrm{C} / \mathrm{Co}_{2} \mathrm{P} / \mathrm{Pd}$ based sensor has high sensitivity of $617 \mathrm{nA} / \mathrm{ppm}$ and its LOD can be determined as $0.25 \mathrm{ppm}$. Meanwhile, it also owns a good linear response in the concentration range of 1-10 ppm. The good performance of $\mathrm{C} / \mathrm{Co}_{2} \mathrm{P} / \mathrm{Pd}$ gas sensor can be analytically attributed to the fast electron transfer from $\mathrm{Co}_{2} \mathrm{P}$ to $\mathrm{Pd}$ nanocrystal. The proposed work provides an alternative way for developing the cost-effective catalyst for fabricating $\mathrm{HCHO}$ gas sensor.

\section{Conflicts of Interest}

The authors declare that they have no conflicts of interest. 


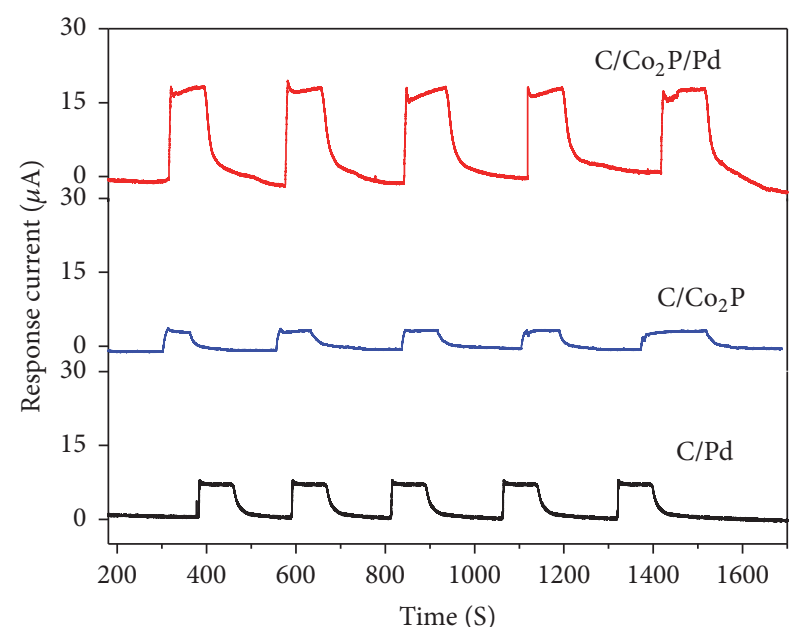

(a)

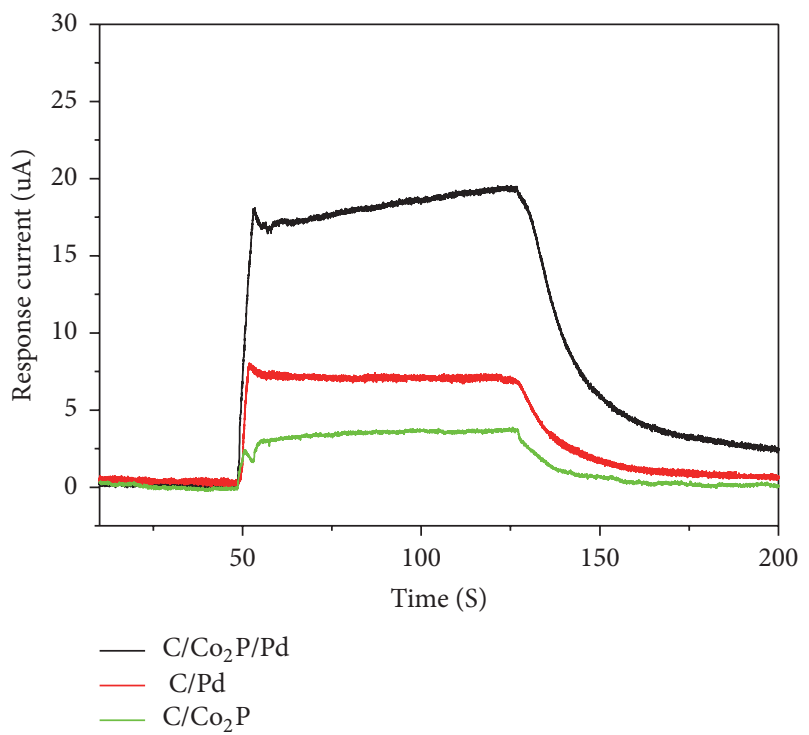

(c)

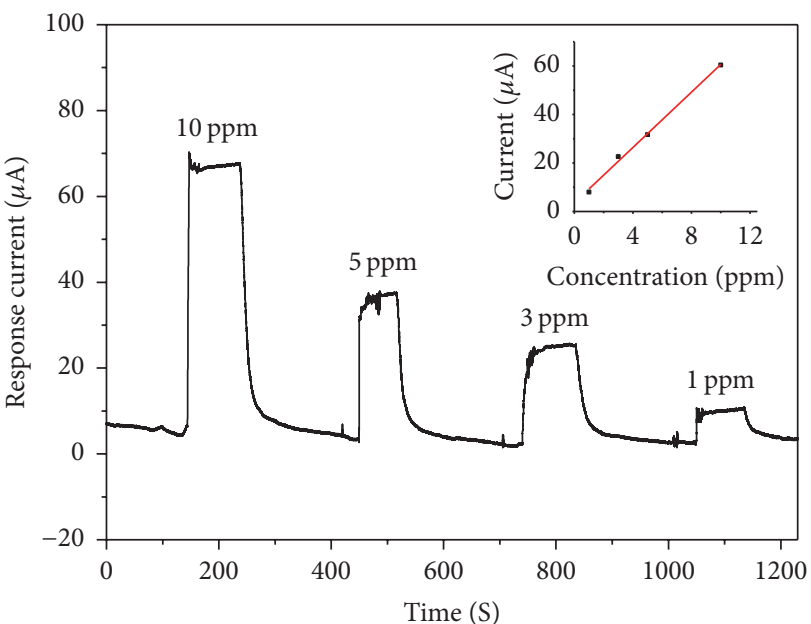

(b)

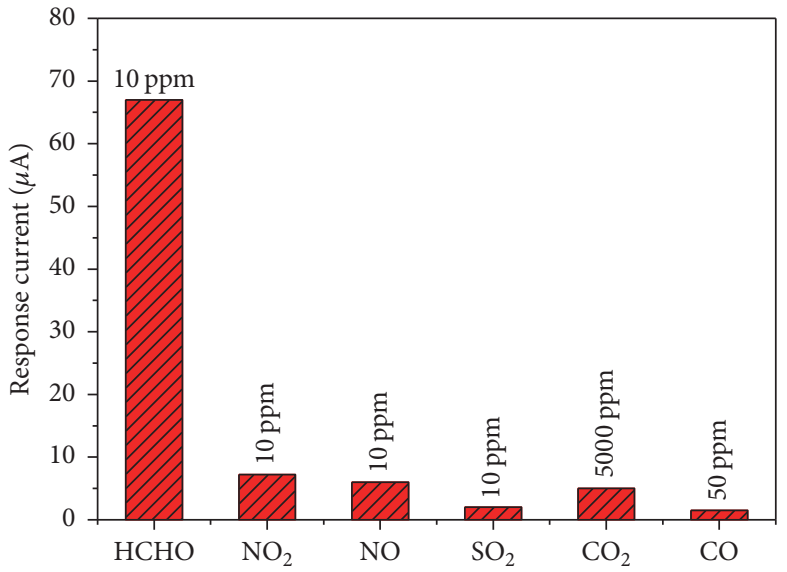

(d)

Figure 9: (a) Amperometric current responses of the $\mathrm{C} / \mathrm{Pd}$ (black line), $\mathrm{C} / \mathrm{Co}_{2} \mathrm{P}$ composite (blue line), and $\mathrm{C} / \mathrm{Co}_{2} \mathrm{P} / \mathrm{Pd}$ (red line) composites based gas sensors to $3 \mathrm{ppm}$ formaldehyde. (b) Typical dynamic current response curves of $\mathrm{C} / \mathrm{Co}_{2} \mathrm{P} / \mathrm{Pd}$ sensor to formaldehyde ranging from $1 \mathrm{ppm}$ to $10 \mathrm{ppm}$ (inset: calibration curve). (c) Enlarged part of the current responses to $3 \mathrm{ppm} \mathrm{HCHO}$ gas of the $\mathrm{C} / \mathrm{Pd}\left(\mathrm{red}\right.$ line), $\mathrm{C} / \mathrm{Co}_{2} \mathrm{P}$ composite (green line), and $\mathrm{C} / \mathrm{Co}_{2} \mathrm{P} / \mathrm{Pd}$ (black line) electrode based gas sensors. (d) Bar plot of current response of the $\mathrm{C} / \mathrm{Co}_{2} \mathrm{P} / \mathrm{Pd}$ composites based formaldehyde sensor to different interfering gases under exposure to $10 \mathrm{ppm}$ formaldehyde, $10 \mathrm{ppm} \mathrm{NO}_{10} 10 \mathrm{ppm} \mathrm{NO}_{2}, 10 \mathrm{ppm} \mathrm{SO}_{2}$, $5000 \mathrm{ppm} \mathrm{CO}_{2}$, and $50 \mathrm{ppm} \mathrm{CO}$. Applied potential to working electrode was $+0.75 \mathrm{~V}$ (versus $\mathrm{Ag} / \mathrm{AgCl}$ ).

\section{Acknowledgments}

This work was supported by the National Natural Science Foundation of China (nos. 51272089, 51672103, and 21575136), National Key R\&D Program of Strategic Advanced Electronic Materials (2016YFB0401103), and the Science and Technology Development Project of Jilin Province, China (nos. 20160204069GX and 20170520169JH).

\section{References}

[1] P.-R. Chung, C.-T. Tzeng, M.-T. Ke, and C.-Y. Lee, "Formaldehyde gas sensors: a review," Sensors, vol. 13, no. 4, pp. 44684484, 2013.
[2] G. R. Mohlmann, "Formaldehyde detection in air by laser induced fluorescence," Applied Spectroscopy, vol. 39, no. 1, pp. 98$101,1985$.

[3] T. Dumas, "Determination of formaldehyde in air by gas chromatography," Journal of Chromatography A, vol. 247, no. 2, pp. 289-295, 1982.

[4] B. Mann and M. L. Grayeski, "New chemiluminescent derivatizing agent for the analysis of aldehydes and ketones by highperformance liquid chromatography with peroxyoxalate chemiluminescence," Journal of Chromatography A, vol. 386, pp. 149157, 1987.

[5] J. M. Lorrain, C. R. Fortune, and B. Dellinger, "Sampling and ion chromatographic determination of formaldehyde and 
acetaldehyde," Analytical Chemistry, vol. 53, no. 8, pp. 1302$1305,1981$.

[6] J. C. Septon and J. C. Ku, "Workplace air sampling and polarographic determination of formaldehyde," AIHAJ, vol. 43, no. 11, pp. 845-852.

[7] B. J. Privett, J. H. Shin, and M. H. Schoenfisch, "Electrochemical sensors," Analytical Chemistry, vol. 82, no. 12, pp. 4723-4741, 2010.

[8] B. Kim, Y. Lu, A. Hannon, M. Meyyappan, and J. Li, "Low temperature $\mathrm{Pd} / \mathrm{SnO} 2$ sensor for carbon monoxide detection," Sensors and Actuators B: Chemical, vol. 177, pp. 770-775, 2013.

[9] S. Tian, X. Ding, D. Zeng, J. Wu, S. Zhang, and C. Xie, "A low temperature gas sensor based on Pd-functionalized mesoporous $\mathrm{SnO}_{2}$ fibers for detecting trace formaldehyde," RSC Advances, vol. 3, no. 29, pp. 11823-11831, 2013.

[10] L. Han, D. Wang, Y. Lu, T. Jiang, B. Liu, and Y. Lin, "Visiblelight-assisted $\mathrm{HCHO}$ gas sensing based on Fe-doped flowerlike $\mathrm{ZnO}$ at room temperature," The Journal of Physical Chemistry C, vol. 115, no. 46, pp. 22939-22944, 2011.

[11] C. Dong, X. Liu, B. Han, S. Deng, X. Xiao, and Y. Wang, "Nonaqueous synthesis of Ag-functionalized In2O3/ZnO nanocomposites for highly sensitive formaldehyde sensor," Sensors and Actuators B: Chemical, vol. 224, pp. 193-200, 2016.

[12] X. Lai, D. Wang, N. Han et al., "Ordered arrays of bead-chainlike $\mathrm{In}_{2} \mathrm{O}_{3}$ nanorods and their enhanced sensing performance for formaldehyde," Chemistry of Materials, vol. 22, no. 10, pp. 3033-3042, 2010.

[13] C. Dong, Q. Li, G. Chen, X. Xiao, and Y. Wang, "Enhanced formaldehyde sensing performance of 3D hierarchical porous structure Pt-functionalized $\mathrm{NiO}$ via a facile solution combustion synthesis," Sensors and Actuators B: Chemical, vol. 220, pp. 171-179, 2015.

[14] C.-H. Chou, J.-L. Chang, and J.-M. Zen, "Effective analysis of gaseous formaldehyde based on a platinum-deposited screenprinted edge band ultramicroelectrode coated with Nafion as solid polymer electrolyte," Sensors and Actuators B: Chemical, vol. 147, no. 2, pp. 669-675, 2010.

[15] S. Liu, K. Hua, Y. Su, X. Lu, C. Li, and Y. J. Wang, "Application of gold hollow nanospheres in amperometric formaldehyde gas sensor," Chinese Journal of Analytical Chemistry, vol. 37, pp. 1092-1096, 2009.

[16] M. Yuan, A. Liu, M. Zhao et al., "Bimetallic PdCu nanoparticle decorated three-dimensional graphene hydrogel for nonenzymatic amperometric glucose sensor," Sensors and Actuators B: Chemical, vol. 190, pp. 707-714, 2014.

[17] Y. Jiang, Y. Lu, F. Li, T. Wu, L. Niu, and W. Chen, "Facile electrochemical codeposition of "clean" graphene-Pd nanocomposite as an anode catalyst for formic acid electrooxidation," Electrochemistry Communications, vol. 19, no. 1, pp. 21-24, 2012.

[18] M. Chen, Z.-B. Wang, K. Zhou, and Y.-Y. Chu, "Synthesis of $\mathrm{Pd} / \mathrm{C}$ catalyst by modified polyol process for formic acid electrooxidation," Fuel Cells, vol. 10, no. 6, pp. 1171-1175, 2010.

[19] B. M. Leonard, Q. Zhou, D. Wu, and F. J. Disalvo, "Facile synthesis of PtNi intermetallic nanoparticles: Influence of reducing agent and precursors on electrocatalytic activity," Chemistry of Materials, vol. 23, no. 5, pp. 1136-1146, 2011.

[20] L. Zhang, Y. Tang, J. Bao, T. Lu, and C. Li, "A carbon-supported Pd-P catalyst as the anodic catalyst in a direct formic acid fuel cell," Journal of Power Sources, vol. 162, no. 1, pp. 177-179, 2006.

[21] J. Jia, R. Wang, H. Wang et al., "A novel structural design of CNx$\mathrm{Fe} 3 \mathrm{O} 4$ as support to immobilize Pd for catalytic oxidation of formic acid," Catalysis Communications, vol. 16, no. 1, pp. 6063, 2011.

[22] X. Wang and Y. Xia, "Electrocatalytic performance of PdCo-C catalyst for formic acid oxidation," Electrochemistry Communications, vol. 10, no. 10, pp. 1644-1646, 2008.

[23] J. Chang, L. Feng, C. Liu, W. Xing, and X. Hu, "An effective Pd-Ni2P/C anode catalyst for direct formic acid fuel cells," Angewandte Chemie International Edition, vol. 53, no. 1, pp.122126, 2014

[24] Z. Zhang, J. Hao, W. Yang, and J. Tang, "Defect-Rich CoP/Nitrogen-Doped Carbon Composites Derived from a Metal-Organic Framework: High-Performance Electrocatalysts for the Hydrogen Evolution Reaction," ChemCatChem, vol. 7, no. 13, pp. 1920 1925, 2015.

[25] J. J. Podestá, R. C. V. Piatti, and A. J. Arvia, “The influence of iridium, ruthenium and palladium on the electrochemical behaviour of Co-P and Ni-Co-P base amorphous alloys for water electrolysis in $\mathrm{KOH}$ aqueous solutions," International Journal of Hydrogen Energy, vol. 20, no. 2, pp. 111-122, 1995.

[26] X. Yang, A.-Y. Lu, Y. Zhu et al., "Rugae-like FeP nanocrystal assembly on a carbon cloth: an exceptionally efficient and stable cathode for hydrogen evolution," Nanoscale, vol. 7, no. 25, pp. 10974-10981, 2015.

[27] L. Song, S. Zhang, and Q. Wei, "A new route for synthesizing nickel phosphide catalysts with high hydrodesulfurization activity based on sodium dihydrogenphosphite," Catalysis Communications, vol. 12, no. 12, pp. 1157-1160, 2011.

[28] B. Tian, Z. Li, W. Zhen, and G. Lu, "Uniformly Sized (112) Facet Co2P on Graphene for Highly Effective Photocatalytic Hydrogen Evolution," The Journal of Physical Chemistry C, vol. 120, no. 12, pp. 6409-6415, 2016.

[29] M. Zuo, L. Pan, T. Sun, D. Zhao, Z. Wang, and H. Geng, "Controlled synthesis of Co2P particles with various morphologies using an in-situ melt reaction," Materials and Corrosion, vol. 90, pp. 858-866, 2016.

[30] M. S. Ahmed and S. Jeon, "Highly active graphene-supported NixPd100-x binary alloyed catalysts for electro-oxidation of ethanol in an alkaline media," ACS Catalysis, vol. 4, no. 6, pp. 1830-1837, 2014.

[31] Q. Hao and Y. Zhang, "Electrochemical degradation of formaldehyde with a novel Pd/GO modified graphite electrode," International Journal of Electrochemical Science, vol. 11, no. 2, pp. 1496-1511, 2016.

[32] D.-D. La, C. K. Kim, T. S. Jun et al., "Pt nanoparticle-supported multiwall carbon nanotube electrodes for amperometric hydrogen detection," Sensors and Actuators B: Chemical, vol. 155, no. 1, pp. 191-198, 2011.

[33] J. R. Stetter and J. Li, "Amperometric gas sensors - A review," Chemical Reviews, vol. 108, no. 2, pp. 352-366, 2008.

[34] M. Rashid, T.-S. Jun, Y. Jung, and Y. S. Kim, "Bimetallic coreshell Ag@Pt nanoparticle-decorated MWNT electrodes for amperometric $\mathrm{H} 2$ sensors and direct methanol fuel cells," Sensors and Actuators B: Chemical, vol. 208, pp. 7-13, 2015. 

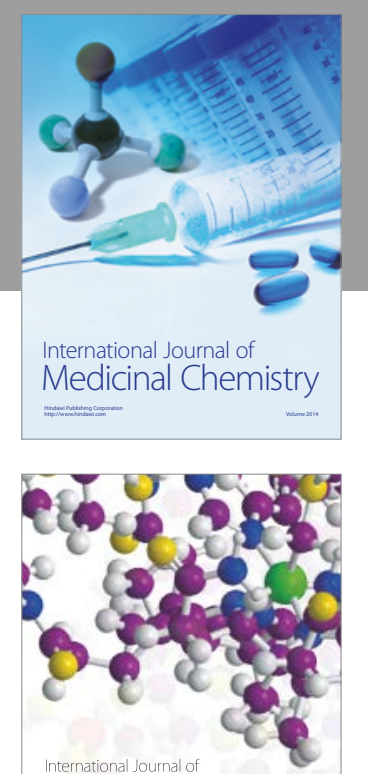

Carbohydrate Chemistry

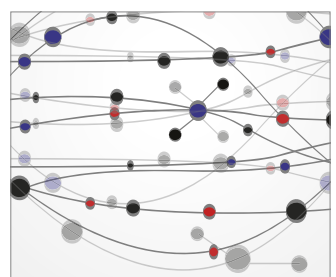

The Scientific World Journal
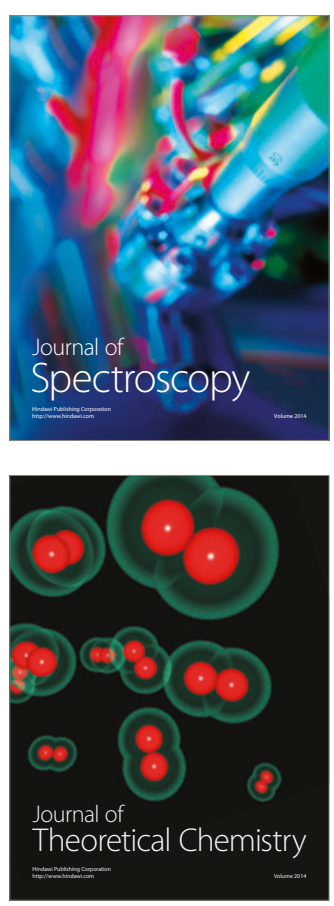
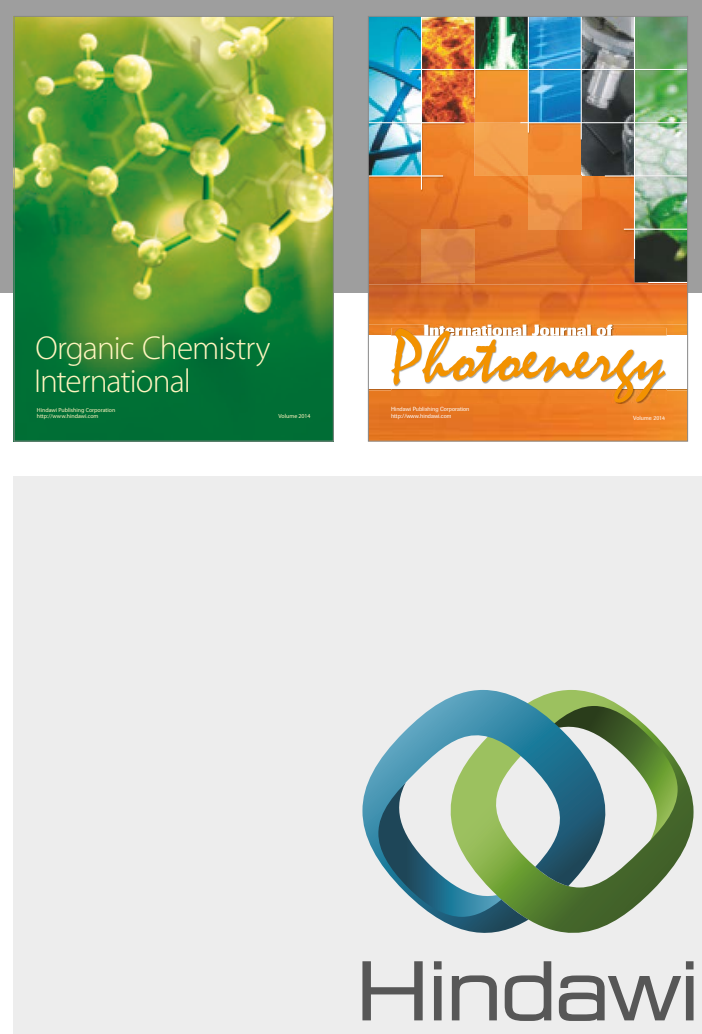

Submit your manuscripts at

https://www.hindawi.com

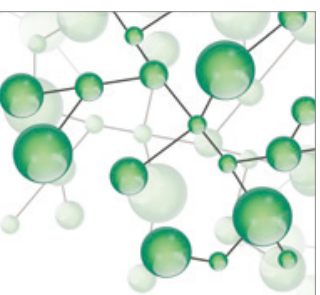

International Journal of

Inorganic Chemistry

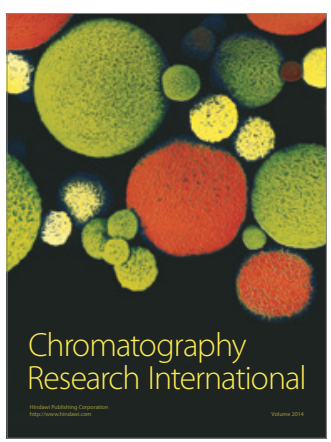

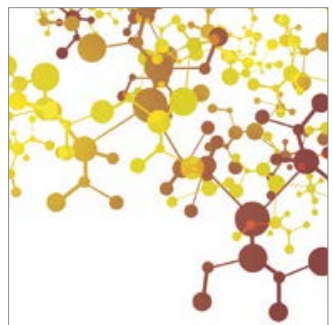

Applied Chemistry
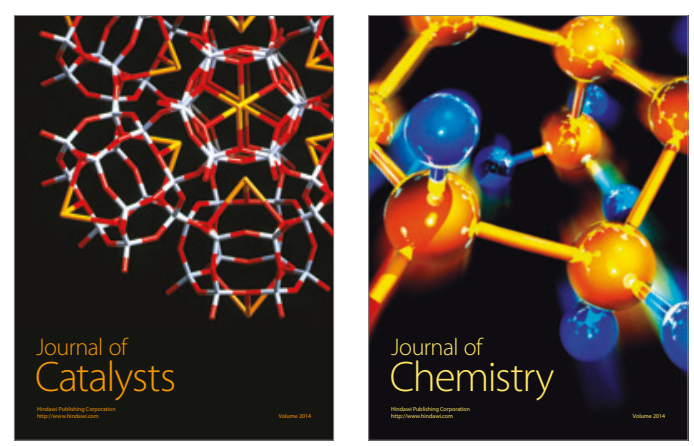
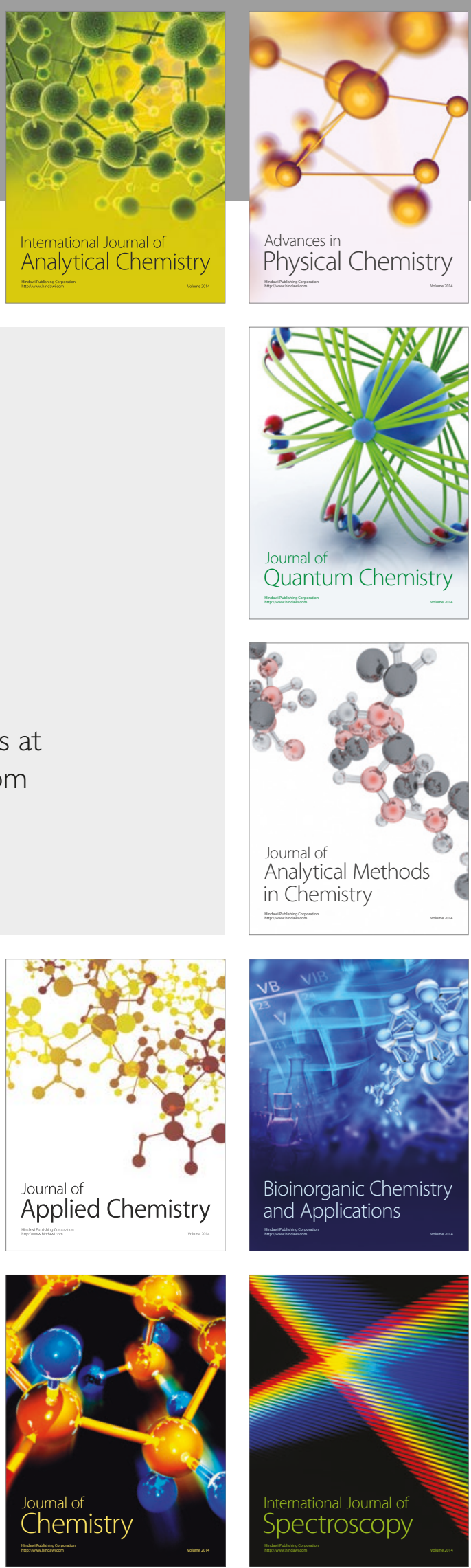